\section{Diversity of containers and buildings infested with Aedes aegypti in Puerto Iguazú, Argentina}

\author{
Diversidad de recipientes y edificios infestados por \\ Aedes aegypti en Puerto Iguazú, Argentina
}

\section{Abstract}

Aedes aegypti is the main domestic vector of the dengue virus. Control measures to prevent dengue transmission focus on the treatment and elimination of this vector's oviposition sites. There is limited biological information on Ae. aegypti in Argentina. The aim of this study was to characterize Ae. aegypti oviposition sites in the city of Puerto Iguazú, Argentina. We surveyed an area covering nine neighborhoods in 2005. We identified 191 premises as positive for Ae. aegypti, giving a general house index of 9.6\%. Premises classified as residential and vacant lots presented the highest number of infested premises, with $9 \%$ and $22 \%$ respectively. The total number of surveyed containers was 29,600. The overall container index (CI) was 1.1. The most frequently infested containers were water tanks $(C I=37)$. These preliminary results suggest that vacant lots and water tanks provide suitable breeding areas and environmental conditions, improving the chances of Ae. aegypti survival in Puerto Iguazú.

Ovoposition; Aedes; Disease Vectors
Federico Costa 1,2

Gladys Fattore 3

Marcelo Abril 3

\section{Introduction}

Dengue is the major cause of human cases of arboviral disease worldwide. Argentina has experienced sporadic dengue outbreaks since the reappearance of the disease in 1998 1. The increasing transmission of dengue in Brazil, Bolivia and Paraguay has been related to epidemics in Northern Argentina 2. Misiones, Formosa and Salta have been the most affected provinces and are located in high-risk zones for dengue transmission in Argentina 2 . In the absence of a vaccine and clinical cures, control of dengue will continue to depend on the reduction of Aedes aegypti populations and mosquito interactions with humans. Control strategies are based on community-based interventions to reduce, eliminate (source reduction) or treat (larvicide) Ae. aegypti-infested containers located in and around households.

Ae. aegypti is a domestic mosquito, which lays eggs preferentially in artificial containers left both indoors and outdoors. The implicit assumption for this dengue control approach is that the identification of container types, permits site specific and cost-effective control programs, that effectively focus on these containers ${ }^{3}$. Although Ae. aegypti is able to lay eggs in a diverse range of objects containing clean water, some types of artificial containers were described as more relevant, due to their availability and large number. Large containers have been especially identified 
as the most important container type because of their large production capacity ${ }^{4}$.

In Argentina, Ae. aegypti reinfestation was detected in 1986 in Puerto Iguazú but imported dengue cases were only reported in 1998 1. Further outbreaks were noted during 2000 and 2006 and were related to the DENV-1 serotype 1,5. The nongovernmental private organization, Fundación Mundo Sano (FMS) has been implementing a program in Puerto Iguazú since 2003 based on the use of larvicides, destruction of development sites and citywide educational activities, in cooperation with the Ministry of Health. Replicating the experience of another city in the North of Argentina 5, Stegomyia indices have been developed to characterize temporal and spatial infestation variations in Puerto Iguazú. Our objective was to investigate the diversity and frequency of types of containers and premises during the period prior to the 2006 dengue outbreak.

\section{Materials and methods}

\section{Study area}

Puerto Iguazú is located at the so called tri-national border between Argentina, Brazil and Paraguay ( $\left.25^{\circ} 35^{\prime} 50^{\prime \prime} \mathrm{S} 54^{\circ} 34^{\prime} 41^{\prime \prime} \mathrm{W}\right)$. The city has a population of 31,000 and the climate is subtropical with no dry season. The cool season (April to September) has an average temperature of $21^{\circ} \mathrm{C}$ and during the hot season (October-March) the temperature reaches $30-35^{\circ} \mathrm{C}$. The annual average cumulative rainfall is $1,900 \mathrm{~mm}$ (monthly variation of $300-550 \mathrm{~mm}$ ) and is concentrated during May to October.

The study was performed in the neighborhoods of Instituto Provincial de Desarrollo Habitacional (IPRODHA), Villa 14, Andresito, Malvinas, Sta. Maria del Iguazú, Villa Tacuara, Zona Hotelera, Villa Florida and Zona Portuaria representing $25 \%$ of the city area. Buildings in this area are mainly individual houses surrounded by small gardens.

\section{Entomological survey}

Between 29 July and 02 November 2005 we surveyed 2,862 premises for the presence of $A e$. aegypti larvae and pupae. Premises were visited by four teams of two trained FMS members. Five percent of the premises were re-visited by a supervisor to evaluate the environmental survey. Premises were classified in five categories depending on their use: residential, commercial, public buildings, vacant lots and others. All water-holding containers in a household were in- spected for the presence of larvae or pupae and recorded on entomological survey forms. If pupae or larvae were encountered, a sample was collected and returned to the FMS laboratory. We recorded the type of container from which larvae or pupae were collected based on the following classifications: (A) tire, (B) drum, barrel, tub, tank and clay containers, (C) flower pots, (D) construction materials and discarded vehicle parts, (E) bottles, cans, and plastic ware, (F) wells and cisterns, $(\mathrm{G})$ Phytothelmata (plants and tree trunks), (H) others containers, (I) water tanks (large tanks $>3 \mathrm{~m}$ from the ground). Measures of the presence of immature mosquitoes were used to estimate entomological risk, including the house index (HI), container index (CI) and Breteau index (BI).

\section{Analysis}

We grouped data by type of container and estimated the frequency of each group. Chi-square was used to compare differences in proportions.

\section{Results}

Surveys were performed in $69 \%$ of the premises sampled $(1,977 / 2,862) ; 31 \%$ of the premises could not be inspected (25\% were closed during at least three visits and in $6 \%$ the owners refused the survey). The proportion of premises inspected varied from $59 \%$ to $85 \%$. Considering the 1,977 premises visited, $71 \%(\mathrm{n}=1,489)$ were classified as residential, and each of the other four categories accounted for less than $10 \%$ of the sample (Table 1).

We identified 191 premises with Ae. Aegypti resulting in a general $\mathrm{HI}$ of $9.6 \%$. Residential and vacant lots presented the highest numbers of infested premises, with 134 and 24 respectively (Table 1). Proportionally, vacant lots and public areas presented higher infestation values $(\mathrm{HI}=$ $22.4 \%$ and $19.1 \%$, respectively). The total number of surveyed containers was 29,600. The most frequent types of container were those classified in categories $E(n=15,328), C(n=6,532), D(n=$ $2,598)$ and $H(n=1,898)$. The following categories presented higher numbers of infested containers: $E(n=129), C(n=43), I(n=37)$ and A ( $n=$ 30). The overall CI was 1.1. The most frequently infested containers were $\mathrm{I}(\mathrm{CI}=37), \mathrm{B}(\mathrm{CI}=3.6)$ and $\mathrm{A}(\mathrm{CI}=2.4$ ) (Table 2).

Villa Florida, Andresito and Malvinas were the neighborhoods with highest HI (18.2, 15.5 and 12.5 respectively). The relationship between infested containers and surveyed premises showed an overall BI of 15.7 (Table 3). 
Aedes aegypti infestation in five types of premises in Puerto Iguazú, Argentina.

\begin{tabular}{|c|c|c|c|}
\hline \multirow[t]{3}{*}{ Type of premises } & \multicolumn{3}{|c|}{ Premises } \\
\hline & Surveyed & Positive to Ae. aegypti & House index \\
\hline & n (\%) & n (\%) & $\%$ \\
\hline Residential & $1,489(75)$ & $134(71)$ & 8.9 \\
\hline Commercial & $178(9)$ & $8(4)$ & 4.5 \\
\hline Public buildings & $56(3)$ & $11(5)$ & 19.0 \\
\hline Vacant lots & $107(5)$ & $24(13)$ & 22.4 \\
\hline Others & $147(8)$ & $14(7)$ & 9.5 \\
\hline Total & $1,977(100)$ & $191(100)$ & 9.6 \\
\hline
\end{tabular}

Table 2

Aedes aegypti infestation in nine types of containers in Puerto Iguazú, Argentina.

\begin{tabular}{lccc}
\hline Container category & $\begin{array}{c}\text { Surveyed } \\
\mathbf{n}(\%)\end{array}$ & $\begin{array}{c}\text { Containers } \\
\text { Infested } \\
\mathbf{n}(\%)\end{array}$ & $\%$ \\
\hline A & $1,270(4)$ & $30(10)$ & 2.4 \\
B & $615(2)$ & $22(7)$ & 3.6 \\
C & $6,532(22)$ & $43(14)$ & 0.7 \\
D & $2,598(9)$ & $11(3)$ & 0.4 \\
E & $15,328(52)$ & $129(41)$ & 0.8 \\
F & $338(1)$ & $5(2)$ & 1.5 \\
G & $920(3)$ & $10(3)$ & 1.1 \\
H & $1,898(6)$ & $25(8)$ & 1.3 \\
I & $101(1)$ & $37(12)$ & 36.6 \\
Total & $29,600(100)$ & $312(100)$ & 1.1 \\
\hline
\end{tabular}

A: tires; B: drum, barrel, tub, tank and clay deposit; C: flower pots; D: construction materials and discarded vehicle parts; E: bottles, cans, and plastic ware; G: wells and cisterns; H: Phytothelamata (plant and tree trunk); I: water tanks (large tanks $>3 \mathrm{~m}$ from the ground).

With regard to the vector control measures performed by the field team, $49 \%$ of the containers were destroyed and $48 \%$ were treated with Temephos (Abate). In 3\% of cases household owners did not authorize the destruction or treatment of the containers. Large tanks and water tanks for human consumption presented a higher refusal rate.

\section{Discussion}

Ae. aegypti is highly adaptive to natural and artificial environments 6 . As shown by previous studies 7 , residential areas were the most frequently infested premises and had the highest number of infested containers. However, in accordance with previous studies, vacant lots and public spaces presented higher levels of infestation suggesting that containers in these areas are covered by vegetation thus offering better shade conditions 7 .

Breteau and housing indices observed in this study were higher than the recommended threshold levels for dengue transmission. However, the epidemiological relationship between entomological indexes and dengue transmission is not clear. In addition, Breteau and housing indexes may not adequately reflect the productivity of adult mosquitoes 8 . Entomological index values were intermediate when compared with other 
Aedes aegypti infestation in nine neighborhoods in Puerto Iguazú, Argentina.

\begin{tabular}{|c|c|c|c|c|c|c|c|}
\hline \multirow[t]{3}{*}{ Neighborhood } & \multicolumn{2}{|c|}{ Premises } & \multicolumn{2}{|c|}{ Containers } & \multicolumn{3}{|c|}{ Index } \\
\hline & Surveyed & Infested & Surveyed & Infested & $\mathrm{HI}$ & $\mathrm{Cl}$ & $\mathrm{BI}$ \\
\hline & n (\%) & n (\%) & n (\%) & n (\%) & $\%$ & $\%$ & $\%$ \\
\hline Villa 14 & $209(11)$ & $36(19)$ & $4,345(15)$ & $84(27)$ & 10.1 & 1.9 & 23.7 \\
\hline Andresito & $92(5)$ & $23(12)$ & 2,803 (9) & $20(6)$ & 15.1 & 0.7 & 13.1 \\
\hline Zona Hotelera & $515(26)$ & $30(16)$ & $5,377(18)$ & $37(12)$ & 3.5 & 0.7 & 4.3 \\
\hline Malvinas & $32(2)$ & $4(2)$ & $1,640(6)$ & $31(10)$ & 12.5 & 1.9 & 96.8 \\
\hline Sta. Maria del Iguazú & 179 (9) & $20(10)$ & $3,348(11)$ & $19(6)$ & 7.4 & 0.6 & 7.1 \\
\hline Villa Tacuara & $227(11)$ & $25(13)$ & $4.541(15)$ & $27(9)$ & 8.9 & 0.6 & 8.9 \\
\hline Villa Florida & $272(14)$ & $14(7)$ & $3,766(13)$ & $18(6)$ & 18.2 & 0.5 & 18.2 \\
\hline Zona Portuaria & $69(3)$ & $9(5)$ & $1,939(7)$ & $18(6)$ & 11.1 & 0.9 & 22.2 \\
\hline Zona Centro & 385 (19) & $30(16)$ & $1,841(6)$ & $58(19)$ & 6.4 & 3.2 & 12.3 \\
\hline Total & $1,977(100)$ & $191(100)$ & $29,600(100)$ & $312(100)$ & 6.6 & 1.1 & 10.9 \\
\hline
\end{tabular}

$\mathrm{BI}$ : Breteau index; $\mathrm{Cl}$ : container index; $\mathrm{HI}$ : house index.

urban studies 4,5,9,10. In two cities in Argentina, entomological indices were higher than in Puerto Iguazú (HI: 67-76\%; CI: 18-39\%; BI: 127-249) 9,10. In the city of Clorinda, with longer standing $A e$. aegypti control programs, lower larval indices (HI of $3 \%$ and $\mathrm{BI}$ of 4 ) were found 5 .

As described by previous studies, Ae. aegypti was found in a heterogeneous range of containers 6 . When analyzing small container categories, $\mathrm{E}$ and $\mathrm{C}$, presented low IC, but were present in large numbers, indicating the potential role that these categories play in dissemination of infestation 6,11 . Tires represented only four percent of the total number of containers and only $2.3 \%$ of this type were infested in contrast with 11 to $34 \%$ observed by other studies 11 . In agreement with results from Brazilian cities 11 large containers (categories B and I) presented higher CI values. Moreover, large containers presented a higher refusal rate for chemical treatment.

This study has limitations. For example, larvae and pupae productivity was not evaluated and stringent quantitative analysis to explore the implications of this factor in terms of larvae and pupae productivity is recommended. Closed or refused premises have also been a frequent limitation in previous studies 5 . Although during this study closed premises were visited three times, it was only possible to inspect $69 \%$ of the premises and the role of the unsurveyed premises regarding Ae. aegypti breeding remains to be addressed. Finally, the survey was performed during August, September and October and increases in temperature from August to September could affect Ae. aegypti breeding and could lead to bias in the study.

Ae aegypti control programs to combat dengue are resource intensive. Identification of target breeding areas is important to maximize both efficacy and efficiency. Preliminary results presented in this study suggest that vacant lots and water tanks provide more suitable breeding areas and environmental conditions thus improving the chances of Ae. aegypti survival in Puerto Iguazú. Further studies on the productivity of adult mosquitoes are recommended in order to improve dengue vector control strategies in Puerto Iguazú. 


\section{Resumen}

El mosquito Aedes aegypti es el vector doméstico más importante del virus dengue. Existe limitada información de la biología del Ae. aegypti en Argentina. Con el fin de identificar los sitios de oviposición de Ae. aegypti en la ciudad de Puerto Iguazú, Argentina, se estudió un área compuesta por nueve barrios durante el año 2005. Se registraron 191 inmuebles positivos sobre un total de 1.977 inspeccionados. La categoría "vivienda" fue la más numerosa, y donde se encontró el mayor número de inmuebles positivos, el porcentaje de infestación fue del 9\%. La categoría "baldio" registró un porcentaje de infestación de 22\%. El número total de recipientes potenciales inspeccionados fue de 29.600 y $1,1 \%$ de los recipientes resultaron positivos. Por otro lado, la mayor proporción de criaderos positivos perteneció a la categoría tanques de altura (37\%). Estos resultados preliminares sugieren que sitios baldios y tanques de altura proveen posibles áreas de reproducción y condiciones ambientales que mejoran las posibilidades de supervivencia de Ae. aegypti.

Ovoposición; Aedes; Vetores de Doenças

\section{Contributors}

F. Costa contributed to the conception, methodological design, and development of the research project, analysis and interpretation of the results and drafting of the article. G. Fattore collaborated in the methodological design and development of the article. M. Abril contributed to the methodological design and critical review of the article.

\section{Acknowledgments}

We are grateful to Fundación Mundo Sano for their financial support.

\section{References}

1. Aviles G, Paz MV, Rangeon G, Ranaivoarisoa MY, Verzeri N, Roginski S, et al. Laboratory surveillance of dengue in Argentina, 1995-2001. Emerg Infect Dis 2003; 9:738-42.

2. Carbajo AE, Schweigmann N, Curto SI, Garin A, Bejaran R. Dengue transmission risk maps of Argentina. Trop Med Int Health 2001; 6:170-83.

3. Morrison AC, Astete H, Chapilliquen F, RamirezPrada C, Diaz G, Getis A, et al. Evaluation of a sampling methodology for rapid assessment of Aedes aegypti infestation levels in Iquitos, Peru. J Med Entomol 2004; 41:502-10.

4. Garelli FM, Espinosa MO, Weinberg D, Coto HD, Gaspe MS, Gurtler RE. Patterns of Aedes aegypti (Diptera: Culicidae) infestation and container productivity measured using pupal and Stegomyia indices in northern Argentina. J Med Entomol 2009; 46:1176-86.

5. Gurtler RE, Garelli FM, Coto HD. Effects of a five-year citywide intervention program to control Aedes aegypti and prevent dengue outbreaks in northern Argentina. PLoS Negl Trop Dis 2009; 3:e427.

6. Focks DA, Sackett SR, Bailey DL, Dame DA. Observations on container-breeding mosquitoes in New Orleans, Louisiana, with an estimate of the population density of Aedes aegypti (L.). Am J Trop Med Hyg 1981; 30:1329-35.

7. Lopes J, Silva MAN, Borsato AM, Oliveira VDRB, Oliveira FJA. Aedes (Stegomyia) aegypti L. e a culicideofauna associada em área urbana da região sul, Brasil. Rev Saúde Pública 1993; 27:326-33.

8. Service MW. Importance of ecology in Aedes aegypti control. Southeast Asian J Trop Med Public Health 1992; 23:681-90.

9. Schweigmann N. Niveles de infestación domiciliaria por Aedes aegypti y Aedes albopictus en la ciudad de El Dorado, Provincia de Misiones, 24 al 27 de abril de 1998. Informe técnico. Buenos Aires: Ministerio de Salud y Acción Social de la Nación; 1998.

10. Stein M, Oria G, Almirón W. Principales criaderos para Aedes aegypti y culícidos asociados, Argentina. Rev Saúde Pública 2002; 36:627-30.

11. Souza-Santos R. Fatores associados à ocorrência de formas imaturas de Aedes aegypti na Ilha do Governador, Rio de Janeiro, Brasil. Rev Soc Bras Med Trop 1999; 32:373-82.

Submitted on 09/Jul/2011

Final version resubmitted on 31/Mar/2012

Approved on 02/Jul/2012 